\title{
Ethnobotanical study of medicinal plants in Imperatriz, State of Maranhão, Northeastern Brazil
}

\author{
Alexandre Batista PENIDO ${ }^{*}$, Selene Maia de MORAIS ${ }^{2}$, Alan Bezerra RIBEIRO ${ }^{3}$, Ana Zélia SILVA ${ }^{4}$ \\ Universidade Federal do Maranhão, Centro de Ciências Sociais Saúde e Tecnologia, Departamento de Enfermagem, Rua Urbano Santos, s/n, Centro, Imperatriz - MA, CEP: \\ $65900-410$ \\ Universidade Estadual do Ceará, Curso de Química, Laboratório de Química e Produtos Naturais, Av. Dr. Silas Munguba, 1.700, Campus do Itaperi, Fortaleza, CE. CEP: 60.714- \\ 903 \\ 3Universidade Federal do Maranhão, Centro de Ciências Sociais Saúde e Tecnologia, \\ Departamento de Engenharia de Alimentos, Rua Urbano Santos, s/n, Centro, Imperatriz-MA. CEP: 65900-410 \\ ${ }^{4}$ Universidade Federal do Maranhão, Centro de Ciências Biológicas e da Saúde, Departamento de Farmácia, Av. dos Portugueses, 1966, Baganga, São Luís - MA. CEP 65080-805 \\ *Corresponding author: alexandre.penido@ufma.br, penidoufma@gmail.com
}

\section{ABSTRACT}

The study of medicinal plants reveals locally important plant species often useful for the discovery of new drugs. The objective of this research was to conduct an ethnobotanical survey of medicinal plants used by the population of the Imperatriz city, State of Maranhão, Northeastern Brazil. Two hundred and five interviews were conducted, resulting in the collection of 60 plant species from 31 plant families. The highest number of species belongs to Fabaceae, followed by Lamiaceae, Asteraceae and Euphorbiaceae. The most reported species were Chenopodium ambrosioides, Myracrodruon urundeuva, Lippia alba, and Plectranthus barbatus. The main plant parts used were leaves (63.3\%), bark (16.7\%), fruits (6.7\%), roots (6.7\%), seeds (3.3), stems (1.7\%) and latex (1.7\%). Major administration routes were by oral $(81.7 \%)$ or nasal via (1.6\%) and topical application $(16.7 \%)$ The plants were used to mitigate various health problems including pain, asthma, hypertension, gastritis, inflammation, influenza, and tuberculosis. The collected data shows that local population uses medicinal plants for treatment of several diseases and this study can serve as a basis for future chemical and pharmacological investigation, which can lead to the discovery of new therapeutic agents.

KEYWORDS: Traditional knowledge; natural products, disease treatment, ethnopharmacology.

\section{Estudo etnobotânico de plantas medicinais em Imperatriz, Estado do Maranhão, Nordeste do Brasil.}

\begin{abstract}
RESUMO
O estudo de plantas medicinais são em geral significativos em revelar espécies de plantas localmente importantes, principalmente para a descoberta de fármacos. O objetivo desta pesquisa foi realizar um levantamento etnobotânico das plantas medicinais utilizadas pela população da cidade de Imperatriz no estado do Maranhão, Nordeste do Brasil. 205 entrevistas foram realizadas resultando na coleção de 60 espécies de 31 famílias de plantas. Fabaceae teve o maior número de espécies, seguido por Lamiaceae, Asteraceae e Euphorbiaceae. As espécies mais utilizadas foram Chenopodium ambrosioides, Myracrodruon urundeuva, Lippia alba e Plectranthus barbatus. As principais partes foram as folhas $(63,3 \%)$, cascas (16,7\%), frutos (6,7\%), raízes (6,7\%), sementes $(3,3 \%)$, caule $(1,7 \%)$ e látex $(1,7 \%)$. As vias de administração mais frequentes foram oral $(81,7 \%)$, tópica (16,7\%) e nasal $(1,6 \%)$. As plantas são utilizadas para diversos problemas de saúde como dores em geral, asma, hipertensão, gastrite, inflamação, gripe e tuberculose. Os dados mostram que população local utiliza plantas medicinais para tratamento de várias doenças e este estudo pode servir de base para estudos químicos e farmacológicos futuros que levem ao descobrimento de novos agentes terapêuticos.
\end{abstract}

PALAVRAS-CHAVES: Conhecimento tradicional; produtos naturais; tratamento de doenças; etnofarmacologia. 


\section{INTRODUCTION}

Brazil presents one of the largest plant biodiversity of the world, with several specific environments and flora types. Along the country, different ethnical groups have introduced the use of many plant species for various purposes, including medicinal (Costa and Mayworm 2011). One factor that favours the use of natural products in Brazil is the ethnobotanical knowledge of the population, which was formed by European and African colonists who brought information about medicinal plants to the local population (Oliveira et al. 2010). There is also indigenous population near Imperatriz city in Maranhão, which may also contributed to local customs in the use of medicinal plants.

Several ethnobotanical studies have been conducted in Brazil, seeking to find out about local folk medicine and forms of organization of this knowledge, and also in the search of plants that have effective therapeutic activity, therefore enabling the discovery of new drugs (Coutinho et al. 2002).

Maranhão, with an area of $331,936 \mathrm{~km}^{2}$, is the eighth largest state in Brazil and the second largest in the Northeastern region of the country. Containing great cultural diversity, it is composed of 217 municipalities, with a population of $6,850,884$. The two main cities of this State are São Luís, the capital city, followed by Imperatriz city (IBGE 2010).

In the state of Maranhão a varied biome is present formed by Caatinga, Amazon rain forest, floodplains, and mangroves and salt marshes, and the Cerrado vegetation going from the South to the Northeast occupying $40 \%$ of the vegetation cover (Silva et al. 2008). The city of Imperatriz (5'31'32" $\mathrm{S}$ and $47^{\circ} 2635^{\prime}$ " W, $92 \mathrm{~m}$ above sea level) is located in the Southwest of the State of Maranhão (Figure 1), at $629.5 \mathrm{~km}$ from São Luís. The total municipality area is $1,368.987 \mathrm{~km}^{2}$ with a population of 247,553 inhabitants, where $94.8 \%$ live in urban areas and $5.2 \%$ in rural areas (IBGE 2010).

The objective of this research was to conduct an ethnobotanical survey of medicinal plants used by local population of Imperatriz city, State of Maranhăo, Northeastern Brazil, providing baseline data for future pharmacological and phytochemical studies of more used plants.

\section{MATERIALS AND METHODS}

The study was submitted and approved by the Ethics Committee of the Federal University of Maranhão (Register No. 814 666). All participants were asked to sign the Informed Consent (IC) prior to data collection. The ethnobotanical study was performed between October 2014 and March 2015 in Imperatriz city, State of Maranhão, in order to investigate and identify plant species used as medicines by the local population.

The questionnaire registers the identification of the interviewed (age, educational background, sex, gender, and socioeconomic data), medicinal plants utilization, forms of use, plant parts, dosages, administration routes and disease indications. The choice of the houses for the interviews was made by chance. For each district, in different streets, five residences were selected, to reach different areas of the city.

A total of 205 questionnaires were applied, generally the respondents had plants at home or the plants were obtained nearby. The botanical material was collected according to the usual methods (Maciel et al. 2002), and deposited in the Ático Seabra Herbarium, Federal University of Maranhão. Taxonomic identification was made according to the vegetative
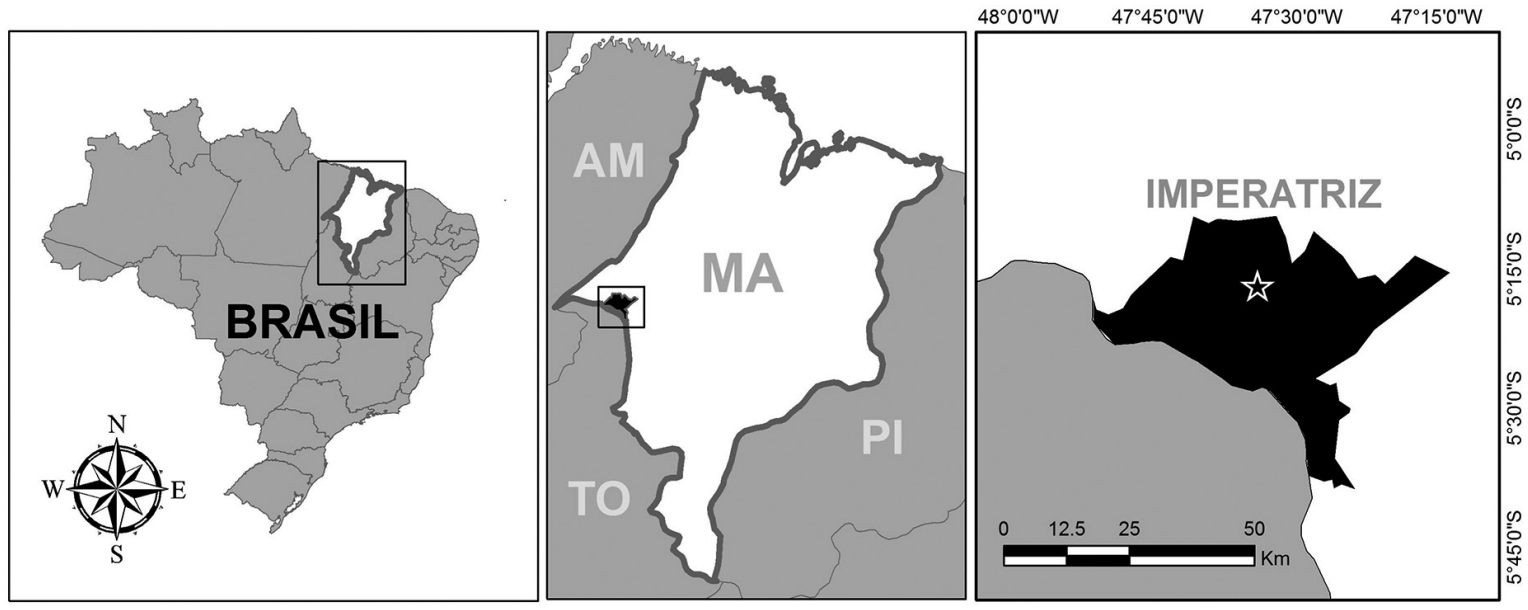

Figure 1. Study area and location map. 
and reproductive morphology (Rego 1995; Coutinho et al. 2002; Monteles and Pinheiro 2007; Lorenzi and Matos 2008).

Data were analysed statistically, and described in simple percentages. The Epi Info Software (version 7.1.5) and Microsoft Excel ${ }^{\circ} 2013$ were used to present the results in figures and tables, considering the relative and absolute values that justify the prevalence of responses. For relative values, parts of medicinal plants used, route of administration, and medicinal plants more cited and for absolute values the number of informants was taken into account. Absolute frequency $(\mathrm{AF})$ is the number of times the element appears in the sample and relative frequency, $\mathrm{AR}(\%)=\mathrm{AF} \times 100 / \mathrm{n}$, where $\mathrm{n}$ is the total number of events.

\section{RESULTS}

In the study the people interviewed were female $(68 \%)$ and male (32\%); the age group varied between 50 and 85 years $(62 \%)$ and between 20 and 49 years (38\%); the educational background was mainly fundamental and medium (48.3\%), incomplete fundamental (25.2\%), university level (14\%) and illiterate (12.5\%); $64.8 \%$ of interviewed have an income below
U\$ 300, 31.4\% below US\$ 300-500 and 3.8\% above U\$ 500 (at exchange rate of march 2015 where US\$1.0 = R \$ 3.18).

The current survey revealed the use of 60 species belonging to 31 families (Table 1), with Fabaceae having the highest number of species, followed by Lamiaceae, Asteraceae and Euphorbiaceae (Table 2). The most used species were: Chenopodium ambrosioides L., Myracrodruon urundeuva Fr. All., Lippia alba (Mill) N. E. Brown and Plectranthus barbatus Andrews.

The most frequently utilized plant part was the leaf (63.3\%), followed by bark (16.7\%), fruit (6.7\%), root (6.7\%), seed (3.3\%), stem (1.7\%) and latex, 1.7\% (Figure 2). Administration routes were by infusion (81.7\%), followed by topical application $(16.7 \%)$ and nasal inhalation $(1.6 \%)$, see Figure 3. The frequency of medicinal plant use varied, depending on the people's health status, with the most common frequency being three times a day. The most common medicinal plant uses were for illnesses involving inflammations; infectious diseases and fever and are shown in Table 1.

Table 1. Ethnobotanical information on the studied medicinal plants, in the state of Maranhão, Northeastern Brazil. (AF= Absolute frequency)

\begin{tabular}{|c|c|c|c|c|c|}
\hline Scientific Names [Family] & Local Name & Used part/preparation & Disease/Use & Register & $\mathrm{AF}$ \\
\hline $\begin{array}{l}\text { Achyrocline satureioides (Lam.) DC } \\
\text { [Asteraceae] }\end{array}$ & Macela & Leaf Infusion & $\begin{array}{l}\text { Memory, stomach pain, } \\
\text { diabetes, back pain, fever }\end{array}$ & 1411 & 4 \\
\hline Ageratum conyzoides L. [Asteraceae] & Mentrasto & Leaf Infusion & Inflammation & 1417 & 1 \\
\hline Aloe vera L. [Liliaceae] & Babosa & Leaf Infusion & $\begin{array}{l}\text { Skin, burn, healing, hair } \\
\text { loss, constipation, stomach } \\
\text { problems }\end{array}$ & 1426 & 6 \\
\hline $\begin{array}{l}\text { Alpinia speciosa } \\
\text { Schum or A. zerumbeth [Zingiberaceae] }\end{array}$ & Jardineira, Colônia & Leaf Infusion & $\begin{array}{l}\text { Flu, blood pressure, asthma, } \\
\text { healing, inflammation }\end{array}$ & 1410 & 4 \\
\hline $\begin{array}{l}\text { Anacardium occidentale Linn } \\
\text { [Anacardiaceae] }\end{array}$ & Caju & Leaf Infusion & Healing, inflammation & 1366 & 6 \\
\hline $\begin{array}{l}\text { Anadenanthera peregrine L. Speg } \\
\text { [Fabaceae] }\end{array}$ & Angico & Bark Decoction & $\begin{array}{l}\text { Expectorant, flu, bronchitis, } \\
\text { asthma, cough }\end{array}$ & 1423 & 4 \\
\hline Annona squamosa L. [Annonaceae] & Ata & Leaf Infusion & $\begin{array}{l}\text { Headache, ulcers, fever, } \\
\text { vermifuge }\end{array}$ & 1101 & 1 \\
\hline Arrabidaea chica Verlot [Bignoniaceae] & Pariri & Leaf Infusion & Anemia, hepatitis & 1067 & 2 \\
\hline Bauhinia forficata Link [Fabaceae] & Mororó & Bark Decoction & Diabetes, kidney problems & 1322 & 2 \\
\hline Bidens pilosa L. [Asteraceae] & Picão & Leaf Infusion & Hepatitis, Malaria & 1285 & 3 \\
\hline Bowdichia virgilioides Kunth [Fabaceae] & Sucupira & Seed Decoction Syrup & $\begin{array}{l}\text { Fever, inflammation, throat } \\
\text { infection }\end{array}$ & 1097 & 3 \\
\hline Capsicum frutescens L. [Solonaceae] & Pimenta Malagueta & Fruit Decoction & $\begin{array}{l}\text { Headache, rheumatism, back } \\
\text { pain }\end{array}$ & 1384 & 1 \\
\hline
\end{tabular}


Table 1. Continuation

\begin{tabular}{|c|c|c|c|c|c|}
\hline Scientific Names [Family] & Local Name & Used part/preparation & Disease/Use & Register & $\mathrm{AF}$ \\
\hline $\begin{array}{l}\text { Caryocar coriaceaum Wittm } \\
\text { [Caryocaraceae] }\end{array}$ & Piqui & Fruit Decoction & Flu, bronchitis, pneumonia & 1325 & 5 \\
\hline Cassia occidentalis L. [Fabaceae] & Fedegoso & Root Decoction & Fever, indigestion & 1397 & 1 \\
\hline $\begin{array}{l}\text { Chenopodium ambrosioides L. } \\
\text { [Chenopodiaceae] }\end{array}$ & Mastruz & Leaf Infusion & $\begin{array}{l}\text { Inflammation, healing, } \\
\text { constipation, flu }\end{array}$ & 1148 & 12 \\
\hline Cissus sicyoides Linn [Vitaceae] & Insulina & Leaf Infusion & Diabetes & 1251 & 4 \\
\hline Copaifera langsdorffii Desf. [Fabaceae] & Copaiba & Bark Decoction & Inflammation, healing & 1400 & 3 \\
\hline Coriandrum sativum L. [Apiaceae] & Coentro & Leaf Infusion & $\begin{array}{l}\text { Menstrual colic, headache, } \\
\text { Inflammation }\end{array}$ & 1418 & 2 \\
\hline Costus spicatus (Jacq.) [Zingiberaceae] & Cana de Macaco & Bark Decoction & $\begin{array}{l}\text { Inflammation, kidney } \\
\text { problems, haemorrhoids }\end{array}$ & 1413 & 1 \\
\hline Eucalyptus globulus Labill [Myrtaceae] & Eucalipto & Leaf Infusion & $\begin{array}{l}\text { Flu, diabetes pneumonia, } \\
\text { bronchitis, }\end{array}$ & 1412 & 5 \\
\hline Euphorbia tirucalli L. [Euphorbiaceae] & Cachorro Pelado & Stem Infusion & Healing & 1045 & 1 \\
\hline Euterpe Oleracea Mart [Arecaceae] & Açaí & Seed Decoction & Memory, high pressure, unwell & 1425 & 1 \\
\hline Genipa americana L. [Rubiaceae] & Genipapo & Bark Decoction & $\begin{array}{l}\text { Inflammation, deregulate } \\
\text { menstruation }\end{array}$ & 1000 & 2 \\
\hline Gossypium arboreum L. [Malvaceae] & Algodão & Leaf Infusion & $\begin{array}{l}\text { Inflammation, cough, bone } \\
\text { healing, asthma }\end{array}$ & 1115 & 7 \\
\hline Hancornia speciosa Gomes [Apocynaceae] & Mangaba & Bark Decoction & $\begin{array}{l}\text { Healing, inflammation, } \\
\text { stomach ulcers, stomach pain }\end{array}$ & 1399 & 2 \\
\hline Jatropha curcas L. [Euphorbiaceae] & Pinhão manso & Leaf Infusion & Inflammation & 1063 & 1 \\
\hline $\begin{array}{l}\text { Julocroton triqueter (Lam) } \\
\text { [Euphorbiaceae] }\end{array}$ & Velame & Leaf Infusion & $\begin{array}{l}\text { Flu, cough, pneumonia, } \\
\text { infection, headache, liver, } \\
\text { rheumatism, blood depurative }\end{array}$ & 1265 & 5 \\
\hline Kalanchoe pinnata Lam. [Crassulaceae] & Folha Santa & Leaf Infusion & $\begin{array}{l}\text { Throat infection, stomach, } \\
\text { healing, pneumonia, flu }\end{array}$ & 1408 & 6 \\
\hline $\begin{array}{l}\text { Lippia alba (Mill) N.E. Brown } \\
\text { [Verbenaceae] }\end{array}$ & Erva Cidreira & Leaf Infusion & $\begin{array}{l}\text { Antiespamodic, sedative } \\
\text { Inflammation }\end{array}$ & 1122 & 9 \\
\hline $\begin{array}{l}\text { Luehea divaricata Mart. \& Zucc } \\
\text { [Malvaceae] }\end{array}$ & Açoita cavalo & Leaf Infusion & $\begin{array}{l}\text { Inflammation, diabetes, } \\
\text { irregular menstruation }\end{array}$ & 1117 & 6 \\
\hline Mangifera indica L. [Anacardiaceae] & Manga & Leaf Infusion & Headache, ulcers, fevers. & 1213 & 4 \\
\hline Mauritia flexuosa Mart. [Arecaceae] & Buriti & Fruit Infusion & $\begin{array}{l}\text { Healing burns, snakebite, } \\
\text { asthma }\end{array}$ & 1394 & 3 \\
\hline Mentha arvensis L. [Lamiaceae] & Vique & Leaf Infusion & Nasal decongestant, flu, cough & 1403 & 4 \\
\hline Mentha villosa L [Lamiaceae] & Hortelã & Leaf Infusion & $\begin{array}{l}\text { Vermifuge, flu, pain, } \\
\text { pneumonia }\end{array}$ & 1424 & 6 \\
\hline Musa paradisiaca L [Musaceae] & Bananeira & Leaf Infusion & Gastritis, flu, bronchitis & 1422 & 3 \\
\hline $\begin{array}{l}\text { Myracrodruon urundeuva Fr. All. } \\
\text { [Anacardiaceae] }\end{array}$ & Aroeira do Sertão & Bark Decoction & $\begin{array}{l}\text { Inflammation, vaginal irregular } \\
\text { menstruation sore throat, } \\
\text { healing }\end{array}$ & 1420 & 10 \\
\hline
\end{tabular}


Table 1. Continuation

\begin{tabular}{|c|c|c|c|c|c|}
\hline Scientific Names [Family] & Local Name & Used part/preparation & Disease/Use & Register & AF \\
\hline Ocimum basilicum L. [Lamiaceae] & Manjericão & Leaf Infusion & $\begin{array}{l}\text { Headache, healing, diuretic, } \\
\text { cough, flu. }\end{array}$ & 1008 & 6 \\
\hline Ocimum gratissimum L. [Lamiaceae] & Alfavaca & Leaf Infusion & Fever, flu, kidney problems & 1372 & 3 \\
\hline Persea americana Mill. [Lauraceae] & Abacateiro & Leaf Infusion & Bladder pain, throat infection, & 1398 & 1 \\
\hline Petiveria alliacea L. [Phytolaccaceae] & Guiné & Leaf Infusion & Fever, joint pain, memory & 1162 & 2 \\
\hline Phyllanthus niruri L. [Euphorbiaceae] & Quebra Pedra & Leaf Infusion & Kidney problems & 1396 & 1 \\
\hline Plathymenia reticulata Benth [Fabaceae] & Candeia & Bark Decoction & $\begin{array}{l}\text { Inflammation, liver problems, } \\
\text { bleeding }\end{array}$ & 1414 & 4 \\
\hline $\begin{array}{l}\text { Plectranthus barbatus Andrews } \\
\text { [Lamiaceae] }\end{array}$ & Brazilian-Boldo & Leaf Infusion & $\begin{array}{l}\text { Stomach ache, hepatitis, } \\
\text { indigestion, liver problems }\end{array}$ & 1406 & 9 \\
\hline Psidium guajava L. [Myrtaceae] & Goiabeira & Leaf Infusion & Diarrhea & 1182 & 3 \\
\hline Rosmarinus officinalis L. [Lamiaceae] & Alecrim & Leaf Infusion & $\begin{array}{l}\text { Flu, nasal decongestant, } \\
\text { sinusitis, anxiety }\end{array}$ & 1392 & 2 \\
\hline Ruta graveolens L. [Rutaceae] & Arruda & Leaf Infusion & $\begin{array}{l}\text { Irregular menstruation, } \\
\text { stomach ache, menstrual } \\
\text { colic, ear pain }\end{array}$ & 1055 & 4 \\
\hline Sambucus nigra L. [Caprifoliaceae] & Sabugueiro & Leaf Infusion & Asthma & 1184 & 1 \\
\hline Scoparia dulcis L. [Scrophulariaceae] & Vassourinha & Bark Decoction & $\begin{array}{l}\text { Inflammation, diuretic and } \\
\text { urinary tract infection }\end{array}$ & 1409 & 1 \\
\hline Solanum paniculatum L. [Solonaceae] & Jurubeba & Leaf Infusion & $\begin{array}{l}\text { Tuberculosis, hepatitis, anti- } \\
\text { inflammatory }\end{array}$ & 1402 & 2 \\
\hline $\begin{array}{l}\text { Stachytarpheta cayennensis (Rich.) Vahl. } \\
\text { [Verbenaceae] }\end{array}$ & Gervão & Leaf Infusion & Inflammation, healing & 1085 & 2 \\
\hline $\begin{array}{l}\text { Stryphnodendron coriaceum Beth } \\
\text { [Fabaceae] }\end{array}$ & Barbatimão & Bark decoction & $\begin{array}{l}\text { Vaginal infection, toothache, } \\
\text { healing, inflammation }\end{array}$ & 1033 & 3 \\
\hline Symphytum officinale L. [Boraginaceae] & Confrei & Leaf Infusion & Healing, cancer, stomach pain & 1096 & 2 \\
\hline $\begin{array}{l}\text { Syzygium aromaticum (L.) Merrill \& Perr } \\
\text { [Myrtaceae] }\end{array}$ & Cravo & Fruit Decoction & $\begin{array}{l}\text { Menstrual colic, pain, anti- } \\
\text { inflammatory, sedative. }\end{array}$ & 1428 & 3 \\
\hline $\begin{array}{l}\text { Tithonia diversifolia Hemsl. Gray } \\
\text { [Asteraceae] }\end{array}$ & Mão de Deus & Leaf Infusion & $\begin{array}{l}\text { Stomach pain, diabetes, } \\
\text { headache, stomach acidity }\end{array}$ & 1419 & 3 \\
\hline $\begin{array}{l}\text { Trattinnickia burserifolia Mart. } \\
\text { [Burseraceae] }\end{array}$ & Amescla & Latex Decoction & Headache, healing & 1416 & 2 \\
\hline Turnera ulmifolia L. [Turneraceae] & Chanana & Leaf Infusion & $\begin{array}{l}\text { Gastritis, back pain, } \\
\text { inflammation }\end{array}$ & 1089 & 4 \\
\hline $\begin{array}{l}\text { Uncaria tomentosa (Willd.) DC. } \\
\text { [Rubiaceae] }\end{array}$ & Unha de gato & Root Decoction & $\begin{array}{l}\text { Gastritis, uterine infection, } \\
\text { sinusitis, headache }\end{array}$ & 1404 & 1 \\
\hline Urtica dioica L. [Urticaceae] & Urtiga & Root Decoction & Inflammation, kidney problems & 1421 & 2 \\
\hline Vernonia brasiliana Less [Asteraceae] & $\begin{array}{l}\text { Assa } \\
\text { Peixe }\end{array}$ & Leaf Infusion & $\begin{array}{l}\text { Flu, pneumonia, expectorant, } \\
\text { asthma, conjunctivitis }\end{array}$ & 1263 & 3 \\
\hline Vitex orinocensis H.B.K [Verbenaceae] & Tarumã & Bark Decoction & Inflammation & 605 & 1 \\
\hline
\end{tabular}


Table 2. Medicinal plants more cited in the state of Maranhão, Northeastern Brazil (AF: Absolute frequency; RF: Relative frequency)

\begin{tabular}{lccccc}
\hline Family & $\mathrm{AF}$ & $\mathrm{RF}(\%)$ & Family & $\mathrm{AF}$ & $\mathrm{RF}(\%)$ \\
\hline Anacardiaceae & 3 & 5.00 & Liliaceae & 1 & 1.67 \\
\hline Annonaceae & 1 & 1.67 & Lauraceae & 1 & 1.67 \\
\hline Apiaceae & 1 & 1.67 & Malvaceae & 2 & 3.33 \\
\hline Apocynaceae & 1 & 1.67 & Musaceae & 1 & 1.67 \\
\hline Arecaceae & 3 & 5.00 & Myrtaceae & 2 & 3.33 \\
Asteraceae & 5 & 8.33 & Phytolaccaceae & 1 & 1.67 \\
\hline Bignoniaceae & 1 & 1.67 & Rubiaceae & 2 & 3.33 \\
Boraginaceae & 1 & 1.67 & Rutaceae & 1 & 1.67 \\
\hline Burseraceae & 1 & 1.67 & Scrophulariaceae & 1 & 1.67 \\
Caprifoliaceae & 1 & 1.67 & Solonaceae & 2 & 3.33 \\
\hline Caryocaraceae & 1 & 1.67 & Turneraceae & 1 & 1.67 \\
Chenopodiaceae & 1 & 1.67 & Urticaceae & 1 & 1.67 \\
Crassulaceae & 1 & 1.67 & Verbenaceae & 3 & 5.00 \\
Euphorbiaceae & 4 & 6.67 & Vitaceae & 1 & 1.67 \\
\hline Fabaceae & 7 & 11.66 & Zingiberaceae & 2 & 3.33 \\
\hline Lamiaceae & 6 & 10.0 & & & \\
Total & & & & 60 & 100 \\
\hline & & & & & \\
\hline
\end{tabular}

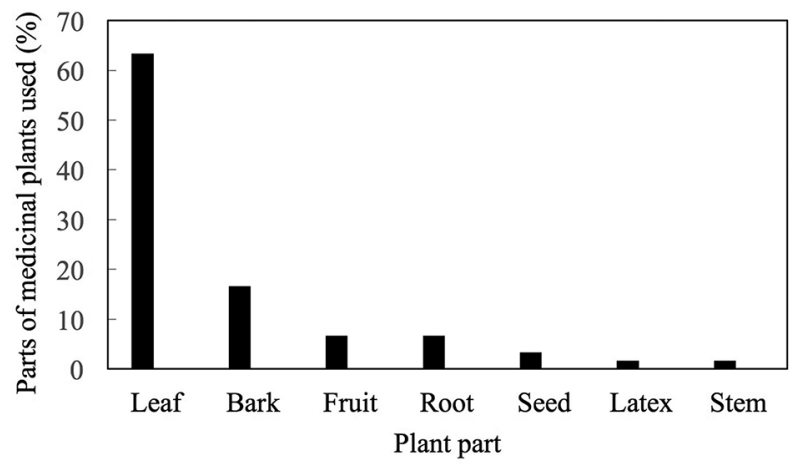

Figure 2. The relative frequency of use of parts of the plant in remedy preparations in the state of Maranhão, Northeastern Brazil.

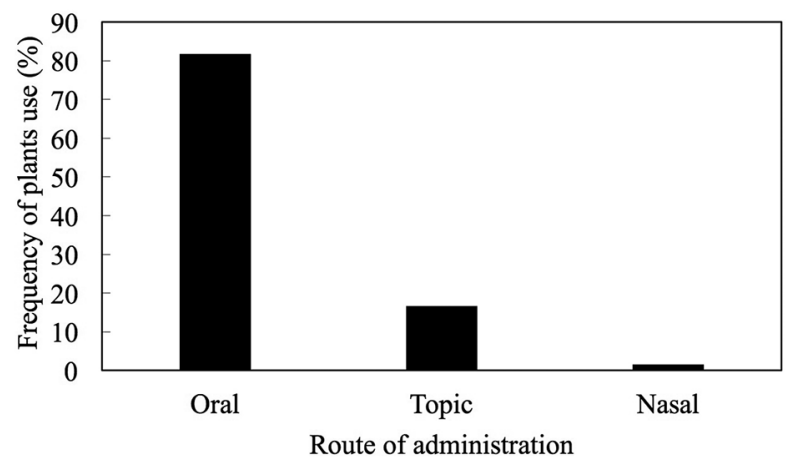

Figure 3. The relative frequency of administration route, with reference to the medicinal plants studied, in the state of Maranhão, Northeastern Brazil.

\section{DISCUSSION}

The current survey revealed the utilization of 60 species of medicinal plants for treatment of 43 health problems, as follows: 21 to treat inflammation, eight for healing, eight for flu, seven for stomach pain, six for menstruation and six for headache. It can be observed that the same plants are used to treat several pathologies. Other problems are less treated with medicinal plants.

The ethnobotanical study performed by Linhares et al. 2014, with medicinal plants commercialized in fairs and markets of São Luis, revealed that most common form of administration was infusion (herbal tea), $58 \%$, followed by bath (12\%). Plant parts used mainly leaves (63.3\%), followed by bark and fruits. Leaves are more easily collected and are found throughout the year, corroborating the observations of Castellucci et al. (2000) and Oliveira et al. (2010). These observations are in accordance with this study, in Imperatriz.

The predominance in the use of plant leaves and bark is often associated with climate and environmental conditions of a region. In the Caatinga biome, for example, present in Northeastern Brazil (equator zone), the temperature is high and varies from $26^{\circ} \mathrm{C}-36^{\circ} \mathrm{C}$, there are prolonged periods of drought, with occurrence of deciduous vegetation which loses its leaves during dry season and then the use of bark is very common. In places where there is still the presence of Atlantic forest or Cerrado, with evergreen vegetation type, with a hot and humid climate, the use of the leaves of medicinal plants for treating various diseases tends to be more frequent (Linhares et al. 2014). This could be seen in the present study, where predominates a tropical and sub-humid climate, and with the presence of the Amazon rainforest.

With regard to the route of administration and dosage the most common forms of plant use is leaf infusion, and dosage varies between one and three cups per day. Oliveira et al. (2010) and Souza et al. (2013) obtained similar results.

Monteles and Pinheiro (2007) studied medicinal species used at a Quilombo in the Maranhão state. They found 121 species, distributed in 56 botanical families. Lamiaceae was the most representative family, followed by Rutaceae, Asteraceae, Leguminosae and Euphorbiaceae. Leaves, bark and latex were the most commonly used plant parts in local medicine preparation, and these results corroborate our study.

The study of Almeida et al. 2012, in the state of Maranhão, found that 339 patients with HIV / AIDS used medicinal plants. The most common were: Turnera ulmifolia, and Plectranthus barbatus which are mainly used for gastric disorders, to treat hypertension, for cardiovascular problems, as bronchodilator, as antitumor, for platelet aggregation inhibition, as anti-inflammatory and antinociceptive agents 
(Costa 2006). In the present study, the most used species were: $C$. ambrosioides, $M$. urundeuva, $L$ alba and $P$. barbatus.

Although C. ambrosioides (mastruz) is largely used around the world as a vermifuge, in Brazil, this species is also used control arthropods and household pests; treatment of cutaneous lesions caused by Leishimania (Vianna) braziliensis (França et al. 1996); relief of stomachache and flu (Moreira et al., 2002) and for treating bruises and fractures (Sérvio et al. 2011). Different uses are probably due to different constituents of the used parts; seed extract and its essential oils combat worms (Kliks 1985), and the leaves are used in inflammation and the treatment of injured body parts.

The toxicity of $C$. ambrosioides is due to the main constituent ascaridol present in the essential oil, especially if used in large quantities, with toxic effects to the kidney, liver, intestine (Pereira et al. 2010), producing slight hepatotoxic lesions (Silva et al. 2014), changes in the nervous system such as headache, facial flushing, blurred vision and paresthesia, and also gastroenteritis with diffuse hyperemia and genotoxic effects (Gadano et al. 2006). Then attention is necessary for the doses of leaf and inflorescence extracts. In our study a peculiarity was observed, $C$. ambrosioides was the species most used by the population, perhaps due to its popularity, its apparent effectiveness, low cost and easy availability (MacDonald et al. 2004).

Myracrodruon urundeuva (aroeira do sertão) is distributed in several states of Brazil, being mainly found in Northeastern region, including Maranhão. It is used as an anti-inflammatory in the treatment of wounds, gastritis, gastric ulcers, cervicitis, vaginitis, and hemorrhoid infections (Lorenzi and Matos 2008, Mello et al. 2013). It is also indicated for treating headaches, toothaches and as an antiseptic and in general inflammation (Cartaxo et al. 2010). It is indicated as antimicrobial (Botelho et al. 2007), antiulcerogenic (Desmarchelier et al.1999) and as gastric mucosa protector (Carlini et al. 2010), having antibacterial, antifungal and bacteriostatic activity (Alves et al. 2009, Menezes et al. 2010; Machado and Oliveira 2014). Myracrodruon urundeuva stands out among medicinal plants with the most nominations in combating health problems in several ethnobotanical surveys of the Caatinga area (Cordeiro and Félix 2014). It is used for the treatment of cancer, inflammation, sore throat, kidney disease, spinal problems, prostate, liver inflammation, diarrhea, gastritis, diphtheria and cough (Silva and Freire 2010; Roque et al. 2010; Marinho et al. 2011). This species was also one of the more commercialized in fairs and markets in Sao Luis, Maranhão (Linhares et al. 2014) confirming the high utilization by the local population of this medicinal plant, as an anti-inflammatory, as well as in Imperatriz. There are many pharmacological studies, which corroborate popular use and analgesic and antiinflammatory activities. It was demonstrated that $M$. urundeuva has a fraction containing three dimeric chalcones (chalcone enriched fraction-CEF), named urundeuvines isolated from the stem-bark ethyl acetate extract (Viana et al. 2003).

Lippia alba (erva sidreira) is an aromatic shrub that belongs to the Verbenaceae family. It is native to South America, and widely distributed. It is known and used in Brazil for different purposes, mainly due to the anxiolytic activity of the tea obtained from its leaves (Santos et al. 2004). The leaf infusion shows antispasmodic action having digestive effect (Blanco et al. 2013), and also present molluscicide action. The species is mainly used for digestive and respiratory ailments, being a sedative and antihypertensive remedy, having anti-infectious and analgesic properties (Hennebelle et al. 2008). Lippia alba and $P$. barbatus species were also the most cited in the work of Madaleno (2011) about main plants used by the population of São Luís.

Plectranthus barbatus (Brazilian-boldo) is widely grown in Brazil and used as a medicinal plant. Despite its main use by the local population for gastric disturbances, a great number of pharmacological actions have been tested and proved for this species: such actions involve compounds present in their leaves, stems, and roots. Among their pharmacological actions, the following can be highlighted: hypotensive, cardiovascular protector, bronchodilator, adenylate cyclise stimulator, platelet aggregation inhibitor (antimetastasis), antitumor, anti-nociceptive and anti-inflammatory (Costa 2006). The study of Madaleno (2011), held in São Luís, showed a high utilization of this species by the population. The compounds barbatusin and 3-beta-hydroxy-3deoxibarbatusin present in $P$. barbatus leaves, demonstrated a gastroprotection action against gastric damage induced by ethanol (Rodrigues et al. 2010). These results indicate that these compounds contribute for the main activity reported for Plectranthus species, to treat gastric disturbances.

\section{CONCLUSIONS}

It was observed that the most common use of medicinal plants is in the treatment of inflammation, wound healing, flu and pain. The plants most used were Chenopodium ambrosioides, Myracrodruon urundeuva, Lippia alba and Plectranthus barbatus. The information obtained contributed to point out medicinal plants from State of Maranhão for future phytochemical and pharmacological studies, aiming the development of new drugs that can be safer and effective for the treatment of diseases. The popular knowledge confirmed by scientific studies can contribute to the rational use of medicinal plants and the importance of preserving them. 


\section{ACKNOWLEDGEMENTS}

The authors would like to Universidade Federal do Maranhão, Universidade Estadual do Ceará, Fundação de Amparo a Pesquisa e ao Desenvolvimento Científico e Tecnológico do Maranhão (FAPEMA) and valuable contributions of all the people we met and interviewed during the field studies.

\section{REFERENCES}

Almeida, F.M., Alves, M.T.S.S.B.; Amaral, F.M.M. 2012. Uso de Plantas com Finalidade Medicinal por Pessoas Vivendo com HIV/ AIDS em Terapia Antirretroviral. Saúde e Sociedade 21: 424-434.

Alves, P.M.; Queiróz, L.M.G.; Pereira, J.V.; Pereira, M.S.V. 2009. Atividade antimicrobiana, antiaderente, antifúngica in vitro de plantas medicinais brasileiras sobre microorganismos do biofilme dental e cepas do gênero Cândida. Revista da Sociedade Brasileira de Medicina Tropical, 42: 222-224.

Blanco, M.A.; Colareda, G.A.; Van Baren, C. Bandoni, A.L.; Ringuelet, J.; Consolini, A.E. 2013. Antispasmodic effects and composition of the essential oils from two South American chemotypes of Lippia alba. Journal of Ethnopharmacology, 149: 803-809.

Botelho, M.A.; Rao, V.S.; Carvalho, C.B.M.; Bezerra-Filho, J.G.; Fonseca, S.G.C.; Vale, M.L.; Montenegro, D.; Cunha, F.; Ribeiro, R.A.; Brito, G.A. 2007. Lippia sidoides and Myracrodruon urundeuva gel prevents alveolar bone resorption in experimental periodontitis in rats. Journal of Ethnopharmacology, 113: 471-478.

Carlini, E.A.; Duarte-Almeida J.M.; Rodrigues, E.; Tabach, R. 2010. Antiulcer effect of the pepper trees Schinus terebinthifolius Raddi (aroeira-da-praia) and Myracrodruon urundeuva Allemão, Anacardiaceae (aroeira-do-sertão). Brazilian Journal of Pharmacognosy, 20: 140-146.

Cartaxo, S.L.; Souza, M.M.A.; Albuquerque, U.P. 2010. Medicinal plants with bioprospecting potential used in semi-arid northeastern Brazil. Journal Ethnopharmacology, 131: 326-342.

Castellucci, S.; Lima, N.I.S.; Nordi, N.; Marques, J.G.W. 2000. Plantas medicinais relatadas pela comunidade residente na Estação Ecológica de Jataí, município de Luís Antonio/SP: uma abordagem etno botânica. Revista Brasileira de Plantas Medicinais, 3: 51-60.

Cordeiro, J.M.P.; Félix, L.P. 2014. Conhecimento botânico medicinal sobre espécies vegetais nativas da Caatinga e plantas espontâneas no agreste da Paraíba, Brasil. Revista Brasileira de Plantas Medicinais, 16: 685-692.

Costa, M.C.C.D. 2006. Uso popular e açôes farmacológicas de Plectranthus barbatus Andr. (Lamiaceae): Revisão dos trabalhos publicados de 1970 a 2003. Revista Brasileira de Plantas Medicinais, 8: 81-88.

Costa, V.P.; Mayworm, M.A.S. 2011. Plantas medicinais utilizadas pela comunidade do bairro dos Tenentes - município de Extrema, MG, Brasil. Revista Brasileira de Plantas Medicinais, 13: 282-292.
Coutinho, D.F.; Travassos, L.M.A.; Amaral, F.M.M. 2002. Estudo etno dirigido de plantas medicinais no Estado do MaranhãoBrasil. Visâo Acadêmica, 3: 7-12.

Desmarchelier, C.; Romão, R.L.; Coussio, J.; Ciccia, G. 1999. Antioxidant and free radical scavenging activities in extracts of medicinal trees used in the Caatinga region in northeastern, Brazil. Journal Ethnopharmacology, 67: 69-77.

França, F.; Lago, E.L.; Marsden, P.D. 1996. Plants used in the treatment of leishmanial ulcers due to Leishmania (Viannia) braziliensis in an endemic area of Bahia, Brazil. Revista da Sociedade Brasileira de Medicina Tropical, 29: 229-232.

Gadano, A.B.; Gurini, A.A.; Carballo, M.A. 2006. Argentine folk medicine: genotoxic effects of Chenopodiaceae family. Journal of Ethnopharmacology, 103: 246-251.

Hennebelle, T.; Sahpaz, S.; Joseph, H.; Bailleul, F. 2008. Ethnopharmacology of Lippia alba. Journal of Ethopharmacology, 116: 211-222

IBGE. 2010. Instituto Brasileiro de Geografia e Estatística- (http:// cidades.ibge.gov.br/xtras/perfil.php?lang=\&codmun $=210530 \&$ search=maranhao(imperatriz). Acesso em 25/09/2015.

Kliks M.M., 1985. Studies on the traditional herbal anthelmintic Chenopodium ambrosioides L.: ethnopharmacological evaluation and clinical field trials. Social Science and Medicine, 21: 879-86.

Linhares, J.F.P.; Hortegal, E. V.; Rodrigues, M.I.A.; Silva, P.S.S. 2014. Ethnobotany of the main medicinal plants commercialized in fairs and markets of São Luis, Maranhão State, Brazil. Revista Pan-Amazônica de Saude, 5: 39-46.

Lorenzi, H.; Matos, F.J.A. 2008. Plantas Medicinais no Brasil: nativas e exóticas cultivadas. 2a ed. Nova Odessa, Instituto Plantarum, Brasil, 512p.

Machado, A.C.; Oliveira, R.C. 2014. Medicamentos Fitoterápicos na odontologia: evidências e perspectivas sobre o uso da aroeirado-sertão (Myracrodruon urundeuva Allemão). Revista Brasileira de Plantas Medicinais, 16: 283-289.

Maciel, M.A.M.; Pinto, A.C.; Veiga Jr., V.F.; Grynberg, N.F.; Echevarria, A. 2002. Plantas medicinais: a necessidade de estudos multidisciplinares. Quimica Nova, 25: 429-438.

MacDonald, D.; VanCrey, K.; Harrison, P.; Rangachan, P.K.; Rosenfeld, J.; Warren, C.; Sorger, G. 2004. Ascaridole-less infusions of Chenopodium ambrosioides contain a nematocide(s) that is(are) not toxic to mammalian smooth muscle. Journal of Ethnopharmacology, 92: 215-221.

Madaleno, I.M. Plantas da medicina popular de São Luís, Brasil. 2011. Boletim do Museu Paraense Emílio Goeldi, 6: 273-286.

Marinho, M.G.V.; Silva, C.C.; Andrade, L.H.C. 2011. Levantamento etnobotânico de plantas medicinais em área de caatinga no município de São José de Espinharas, Paraíba, Brasil. Revista Brasileira de Plantas Medicinais, 13: 170-182.

Mello, M.J.R.; Leite, J.A.D., Vasconcellos, R.J.H.; Morais, H.H.A.M. 2013. Atividade anti-inflamatória, cicatrizante e antimicrobiana do extrato aquoso de aroeira-do-sertão a 20\% (Myracrodruon urundeuva Fr. All.) aplicado em fraturas expostas induzidas em mandíbula de coelho. Revista de Cirurgia e Traumatologia Buco-Maxilo-Facial, 13: 97-104. 
Menezes, T.E.C.; Delbem, A.C.B.; Brighenti, F.L.; Okamoto, A.C.; Gaetti-Jardim Jr, E. 2010. Protective efficacy of Psidium cattleianum and Myracrodruon urundeuva aqueous extracts against caries development in rats. Pharmaceutical Biology, 48: 300-305.

Monteles, R.; Pinheiro, C.U.B. 2007. Plantas medicinais em um quilombo maranhense: uma perspectiva etnobotânica. Revista de Biologia e Ciências da Terra, 7: 38-48.

Moreira, R.C.T.; Costa, L.C.B.; Costa, R.C.S.; Rocha, E.A. 2002. Abordagem etnobotânica acerca do uso de plantas medicinais na Vila Cachoeira, Ilhéus, Bahia, Brasil. Acta Farmacéutica Bonaerense, 21: 205-211.

Oliveira, H.B.; Kffuri, C.W.; Casali, V.W.D. 2010. Ethnopharmacological sudy of medicinal plants used in Rosario da Limeira, Minas Gerais, Brazil. Revista Brasileira de Farmacognosia, 20: 256-260.

Pereira, W.S.; Ribeiro, B.P.; Sousa, A.I.P.; Serra, I.C.P.B.; Mattar, N.S.; Fortes, T.S.; et al. 2010. Evaluation of the subchronic toxicity of oral treatment with Chenopodium ambrosioides in mice. Journal of Ethnopharmacology, 127: 602-605.

Rego, T.J.A., 1995. Fitogeografia das Plantas Medicinais no Maranhão. 2a. edição Editora UFMA, São Luís, Brasil, 150p.

Rodrigues, P.A.; Morais, S.M.; Souza, C.M.: Silva, A.R.; Andrade, A.M.; Silva, M.G.V.; Albuquerque, R.L. 2010. Gastroprotective effect of barbatusin and 3-beta-hydroxy-3deoxibarbatusin, quinonoid diterpenes isolated from Plectranthus grandis, in ethanol-induced gastric lesions in mice. Journal of Ethnopharmacology, 127: 725-730.

Roque, A.A.; Rocha, R.M.; Loiola, M.I.B. 2010. Uso e diversidade de plantas medicinais da Caatinga na comunidade rural de Laginhas, município de Caicó, Rio Grande do Norte (Nordeste do Brasil). Revista Brasileira de Plantas Medicinais, 12: 31-42.
Santos, M.R.A.; Innecco, R.; Soares, A.A. 2004. Caracterização anatômica das estruturas secretoras e produçáo de óleo essencial de Lippia alba (Mill.) N.E. Br. em função do horário de colheita nas estaçōes seca e chuvosa. Revista Ciência Agronômica, 35: 377-383.

Sérvio, E.M.L.; Araújo, K.S.; Nascimento, L.R.S.; Costa, C.L.S.; Mendes, L.M.S.; Filho, A.L.M.M.; Santos, I.M.S.P. 2011. Cicatrização de feridas com a utilização do extrato de Chenopodium ambrosioides (mastruz) e cobertura secundária estéril de gaze em ratos. Conscientiae Saúde, 10: 441-448

Silva, H.G.; Figueiredo, N.; Andrade, G.V. 2008. Estrutura da vegetação de um cerradáo e a heterogeneidade regional do cerrado do Maranhão, Brasil. Revista Árvore, 32: 921-930.

Silva, T.S.; Freire, E.M.X. 2010. Abordagem etnobotânica sobre plantas medicinais citadas por populaçóes do entorno de uma unidade de conservação da caatinga do Rio Grande do Norte, Brasil. Revista Brasileira de Plantas Medicinais, 12: 427-435.

Silva, M.G.; Amorin, R.N.; Câmara, C.C.; Fontenele Neto, J.D.; Soto-Blanco, B. 2014. Acute and sub-chronic toxicity of aqueous extracts of Chenopodium ambrosioides leaves in rats. Journal of Medicinal Food, 17: 979-984.

Souza, C.M.P.; Brandão, D.O.; Silva, M.S.P.; Palmeira, A.C.; Simôes, M.O.S.; Medeiros, A.C.D. 2013. Utilização de Plantas Medicinais com Atividade Antimicrobiana por Usuários do Serviço Público de Saúde em Campina Grande - Paraíba. Revista Brasileira de Plantas Medicinais, 15: 188-193.

Viana, G.S.G.; Bandeira, M.A.M.; Matos, F.J.A. 2003. Analgesic and anti-inflammatory effects of chalcones isolated from Myracrodruon urundeuva Allemao. Phytomedicine, 10: 189-195.

Recebido em 06/03/2016

Aceito em 09/06/2016 
